\title{
DINAMIKA PENGEMBANGAN KLASTER INDUSTRI PERSUSUAN DI KABUPATEN SEMARANG, JAWA TENGAH
}

\section{DYNAMICS OF DAIRY INDUSTRY CLUSTER DEVELOPMENT IN SEMARANG REGENCY, CENTRAL JAVA}

\author{
Riyuni Asih*, Tridjoko Wisnu Murti, dan F. Trisakti Haryadi \\ Fakultas Peternakan, Universitas Gadjah Mada, Jl. Fauna No. 3, Bulaksumur, Yogyakarta, 55281
}

\section{INTISARI}

Penelitian ini bertujuan untuk menganalisis dinamika pengembangan klaster industri persusuan di Kabupaten Semarang Provinsi Jawa Tengah. Dinamika pengembangan klaster industri persusuan dianalisis melalui kekuatankekuatan yang ada pada setiap elemen-elemen klaster, yaitu pemasok bahan baku susu, industri inti, industri terkait, industri pendukung, pembeli, dan lembaga pendukung. Responden yang digunakan dalam penelitian ini adalah pihakpihak yang terkait (stakeholders) dalam klaster industri persusuan di Kabupaten Semarang, terdiri dari peternak sapi perah, koperasi susu, Industri Pengolahan Susu, industri terkait, dan lembaga pendukung. Alat bantu yang digunakan adalah kuesioner. Penelitian ini menggunakan metode survei dengan menggunakan data primer dan sekunder. Analisis data yang digunakan adalah analisis deskriptif. Hasil dari penelitian menunjukkan bahwa pada tingkat pemasok, rata-

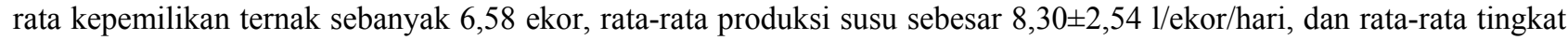
adopsi sebesar 57,57\%. Produksi susu di tingkat koperasi sebesar $77.300 \mathrm{~kg}$ /hari. Rata-rata kualitas susu adalah 6,78 ( $\mathrm{pH}$ ), 11,23\% (total solid), 3,55\% (lemak), 7,68\% (SNF), 2,68\% (protein), dan 4,45\% (laktosa). Kuota pembelian dari industri pengolahan susu yaitu $212.000 \mathrm{~kg} / \mathrm{hari}$. Bank sebagai industri pendukung telah memberikan pinjaman modal pada pengusaha persusuan sebesar Rp24.892.000.000,00. Institusi pendukung telah melakukan peran masing-masing.

(Kata kunci: Dinamika, Klaster, Industri persusuan)

\section{ABSTRACT}

The aim of this study was to analyze dynamics of the cluster development in the dairy industry cluster in Semarang Regency. Dynamics of dairy cattle cluster development had seen in each cluster elements, namely raw milk suppliers, core industries, related industries, supporting industries, buyers and supporting institutions. The respondents in this study were stakeholders in the dairy industry cluster in Semarang Regency, dairy farmers, dairy cooperatives, dairy processing industry, related industries, and supporting institutions. The data were analyzed using descriptive analysis. Result showed that in the suppliers there were the average of livestock ownership 6.58 head, the average of milk production $8.30 \pm 2.54$ l/head/day and adoption rate $55.57 \%$. The production of milk in core industries (cooperatives) was 77,300 kg/day. The quality of milk was 6.78 ( $\mathrm{pH}$ value), $11.23 \%$ (total solid), $3.55 \%$ (fat), $7.68 \%$ (SNF), $2.68 \%$ (protein) and $4.45 \%$ (lactose). The quota of the buyers dairy processing industries was 212,000 kg/day. Banks, as supporting industries, have given capital loan Rp24,892,000.00. The supporting institutions have done their own role.

(Key words: Dynamics, Cluster, Dairy industry)

\section{Pendahuluan}

Upaya pemerintah sesuai Peraturan Presiden RI No. 28 Tahun 2008 tentang Kebijakan Industri Nasional antara lain menerangkan bahwa produk susu termasuk prioritas untuk dikembangkan di provinsi maupun kabupaten/kota. Susu merupakan salah satu produk unggulan Jawa Tengah yang perlu dikembangkan, terutama di sentra penghasil susu di Kabupaten Semarang. Pengembangan industri persusuan salah satunya adalah dengan pembentukan klaster industri. Klaster merupakan perkiraan pengelompokan geografis dari sejumlah industri

\footnotetext{
*Korespondensi (corresponding author):

Telp. +62 85643295995

E-mail: riyuni.asih@yahoo.com
}

yang saling terkait kegiatannya dan terhubungkan dalam satu komunitas serta saling melengkapi (Porter, 2002).

Klaster industri adalah nyata dan mempelajari fenomena ekonomi dan memainkan peran yang sangat penting dalam pembangunan ekonomi regional (Xiaohui et al., 2006). Klaster memiliki beberapa pihak atau elemen yang mendukung berjalannya suatu klaster industri. Setiap pihak atau pelaku dalam klaster industri memiliki tugas, peran, dan potensi tertentu dalam klaster industri tersebut dan terkait satu dengan lainnya dalam rantai nilai (value chain). Rantai nilai menggambarkan berbagai kegiatan yang dibutuhkan untuk membawa produk atau layanan melalui fase perantara produksi sampai pengiriman ke konsumen akhir (Kaplinsky, 
2000). Konsep rantai nilai (value chain) diadopsi dan banyak digunakan karena dianggap paling inklusif dari berbagai rantai aktivitas dan produk akhir (Gereffi et al., 2001).

Keterkaitan antara satu pihak dan lainnya dapat berupa hubungan bisnis maupun non-bisnis. Himpunan pelaku, keterkaitan dan dinamika proses dalam klaster industri persusuan menjadikan klaster tersebut dapat dipandang sebagai suatu "sistem" (kesatuan). Untuk itu diperlukan informasiinformasi terkait dengan dinamika dalam pengembangan klaster susu di Jawa Tengah, khususnya di Kabupaten Semarang. Penelitian ini bertujuan untuk menganalisis dinamika pengembangan klaster industri persusuan di Kabupaten Semarang.

\section{Materi dan Metode}

Penelitian dilakukan Kabupaten Semarang, Provinsi Jawa Tengah. Responden yang digunakan dalam penelitian ini adalah pihak-pihak yang terkait (stakeholders) dalam klaster industri persusuan di Kabupaten Semarang, mulai dari peternak sapi perah, koperasi susu, Industri Pengolahan Susu (IPS), industri terkait, dan lembaga pendukung. Alat bantu yang digunakan adalah kuesioner.

Peternak yang digunakan sebagai responden diambil 50 orang peternak sapi perah. Responden tersebut ditentukan secara convenience sampling. Penggunaan metode sampling ini karena peternak tersebar tidak merata di Kabupaten Semarang dan sebagian bukan anggota koperasi. Penentuan koperasi susu yang digunakan dalam penelitian ini ditentukan dengan cara purposive sampling (Cooper dan Schindler, 2006). Penggunaan purposive sampling tersebut dilakukan karena dipilih koperasi di Kabupaten Semarang yang bergerak dengan bidang usaha utama adalah persusuan. Responden dari pihak terkait atau stakeholders yang diwawancarai merupakan pihak yang berwenang dalam melaksanakan fungsi.

Data yang digunakan dalam penelitian ini adalah data primer dan sekunder. Pengumpulan data primer dilakukan dengan observasi dan wawancara yaitu pengumpulan data dengan cara meminta keterangan melalui daftar pertanyaan dengan menggunakan kuesioner serta pertanyaan mendalam (Cooper dan Schindler, 2006; Bebe et al., 2003). Data sekunder menggunakan teknik pencatatan, yaitu pengumpulan data dengan cara mencatat data yang telah ada pada instansi terkait. Pengukuran ariabel penelitian pada masing-masing elemen klaster dianalisis secara deskriptif (Tabel 1).

\section{Hasil dan Pembahasan}

Industri persusuan di Kabupaten Semarang terutama dititik beratkan pada tingkat produsen susu sampai ke koperasi susu. Hal tersebut dikarenakan, sebagian besar produksi susu dibeli oleh IPS kemudian dibawa ke pabrik yang berlokasi di luar

Tabel 1. Pengukuran variabel penelitian (measurement of research variable)

\begin{tabular}{|c|c|}
\hline Komponen (component) & Pengukuran (measurement) \\
\hline \multicolumn{2}{|l|}{ Pemasok (supplier) } \\
\hline $\begin{array}{l}\text { Rata-rata kepemilikan ternak (average of cattle } \\
\text { ownership) }\end{array}$ & Data wawancara peternak/data primer (primary data) \\
\hline $\begin{array}{l}\text { Rata-rata produksi susu (average of milk } \\
\text { production) }\end{array}$ & Data wawancara peternak (primary data) \\
\hline Tingkat adopsi (adoption rate) & Data wawancara peternak (primary data) \\
\hline \multicolumn{2}{|l|}{ Industri inti (core industries) } \\
\hline Kuantitas/produksi susu (milk quantity) & Data sekunder (secondary data) \\
\hline Kualitas susu (milk quality) & Data sekunder (secondary data) \\
\hline \multicolumn{2}{|l|}{ Pembeli (buyer) } \\
\hline Kuota penerimaan (admission quota) & $\begin{array}{l}\text { Data wawancara dan melihat data sekunder (primary } \\
\text { and secondary data) }\end{array}$ \\
\hline \multicolumn{2}{|l|}{ Industri terkait (related industries) } \\
\hline $\begin{array}{l}\text { Banyaknya industri susu skala kecil dan } \\
\text { produksinya (production of small scale milk } \\
\text { industries) }\end{array}$ & $\begin{array}{l}\text { Data sekunder dan wawancara (interview and } \\
\text { secondary data) }\end{array}$ \\
\hline \multicolumn{2}{|l|}{ Industri pendukung (supporting industries) } \\
\hline Jumlah kredit (amount of credit) & $\begin{array}{l}\text { Data sekunder dan wawancara dengan staf bank dan } \\
\text { peternak (interview with banking staff and farmers and } \\
\text { secondary data) }\end{array}$ \\
\hline $\begin{array}{l}\text { Institusi pendukung (supporting institutions) } \\
\text { Institusi yang terkait (related institutions) }\end{array}$ & $\begin{array}{l}\text { Data sekunder dan wawancara (interview and } \\
\text { secondarydata) }\end{array}$. \\
\hline
\end{tabular}


Kabupaten Semarang, bahkan ada yang sampai ke luar Provinsi Jawa Tengah dan sebagian kecil IPS skala kecil di wilayah Kabupaten Semarang dan Kota Salatiga.

Badan Pengkajian dan Penerapan Teknologi (2011) membagi klaster dalam beberapa elemen pendukung klaster, yaitu pemasok, industri inti, industri terkait, industri pendukung, pembeli, dan institusi atau lembaga pendukung. Kelompok elemen atau komponen klaster persusuan yang melibatkan kontribusi pihak-pihak terkait dalam rantai nilai di Jawa Tengah tersaji pada Gambar 1.

\section{Pemasok}

Peternak sapi perah sebagai pemasok bahan baku, merupakan aspek penting dalam pendukung kekuatan klaster industri persusuan. Peternakan sapi perah merupakan penyedia utama bahan baku susu sebagai komoditas usaha persusuan. Sebagian besar peternak sapi perah di Kabupaten Semarang adalah peternak rakyat dengan skala kepemilikan kecil yaitu 6 ekor. Berdasarkan survei yang telah dilakukan pada 50 orang peternak di Kabupaten Semarang, rata-rata kepemilikan ternak oleh peternak tesebut dapat dilihat pada Tabel 2 .

Tabel 2 menunjukkan bahwa sapi perah yang banyak dimiliki oleh peternak adalah sapi laktasi dengan persentase sebesar $63,83 \%$, sedangkan paling sedikit adalah sapi jantan karena sebagian besar peternak menggunakan inseminasi buatan untuk mengawinkan sapinya. Rata-rata kepemilikan sapi perah sebanyak 6,58 ekor, sedangakan rata-rata kepemilikan sapi laktasi sebanyak 4,20 ekor.
Prasetyo (2008) menyatakan kepemilikan sapi di Jawa Tengah rata-rata 2 sampai 5 ekor. Produksi susu rata-rata di tingkat peternakan rakyat yaitu $8,30 \pm 2,54$ 1/ekor/hari.

Pada tingkat peternak, selalu didorong untuk menghasilkan susu dengan kualitas dan kuantitas yang baik agar mendapatkan harga beli yang tinggi. Inovasi sangat diperlukan dalam usaha memperoleh kualitas susu yang memenuhi standar dan kuantitas yang tinggi. Berdasarkan hasil wawancara rata-rata sebanyak 57,57\% peternak di Kabupaten Semarang mengadopsi inovasi dalam manajemen pemeliharaan sapi perah. Tingkat adopsi penggunaan pakan konsentrat sebagai pakan memiliki persentase paling tinggi yaitu sebanyak $100 \%$, diikuti dengan rumput unggul dan inseminasi buatan (IB) sebanyak 96\%, sedangkan penggunaan leguminosa, silase, milk can, dan recording masih di bawah 50\% (Tabel 3).

Tingkat adopsi untuk recording atau pencatatan kurang dari $50 \%$ dan pencatatan yang dilakukan oleh peternak masih sebatas tanggal kawin dan tanggal lahir. Persentase peternak yang melakukan adopsi penerapan penggunaan milk can kurang dari 50\%. Hasil tersebut menunjukkan masih banyak peternak yang tidak menggunakan milk can dalam menampung dan menyetorkan susu. Peternak menggunakan ember plastik dan atau drum plastik untuk menampung dan menyetorkan susu. Alat-alat berbahan plastik tersebut sangat rentan dalam menjaga susu dari kontaminasi mikrobia dan kotoran (Vissers, 2007). Ironisnya, dalam observasi ditemui pula peternak yang menggunakan ember

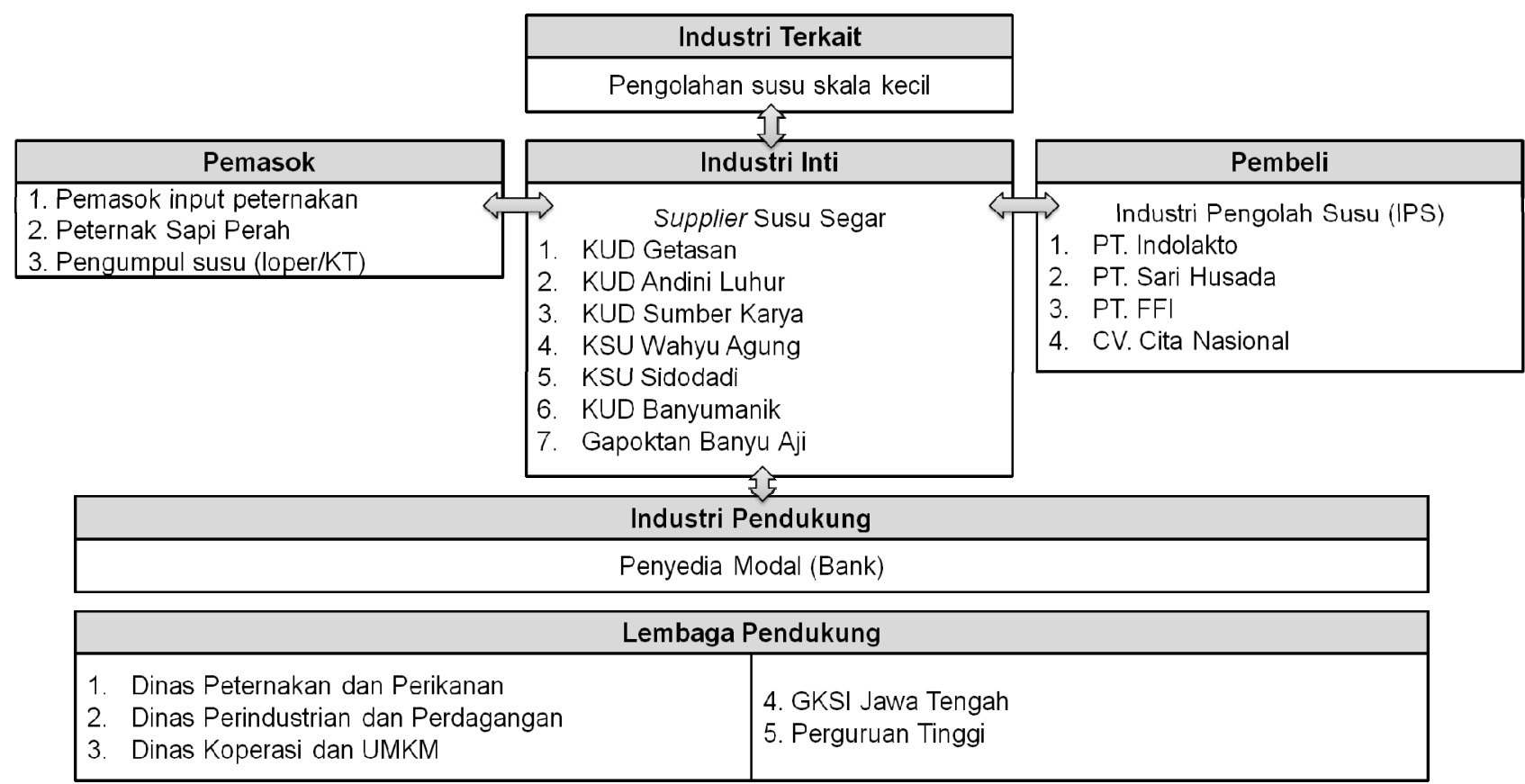

Gambar 1. Elemen-elemen klaster industri persusuan di Kabupaten Semarang (elements of dairy industry cluster in Semarang Regency). 
Tabel 2. Rerata kepemilikan sapi perah (average of dairy cattle ownership)

\begin{tabular}{|c|c|c|c|}
\hline Status sapi (ekor) (cow status (head)) & $\begin{array}{l}\text { Jumlah (unit ternak) } \\
\text { (amount (animal unit)) }\end{array}$ & $\begin{array}{l}\text { Jumlah (ekor) } \\
\text { (amount (head)) }\end{array}$ & $\begin{array}{l}\text { Persentase } \\
\text { (percentage) }\end{array}$ \\
\hline Sapi laktasi (lactating cow) & 210 & 210 & 63,83 \\
\hline Sapi kering (dried cow) & 25 & 25 & 7,60 \\
\hline Jantan (bull) & 2 & 2 & 0,61 \\
\hline Dara (heifer) & 6 & 12 & 3,65 \\
\hline Pedet (calf) & 20 & 80 & 24,32 \\
\hline Jumlah (amount) & 263 & 329 & 100 \\
\hline Rata-rata kepemilikan (average of cattle ownership)* & 5,26 & 6,58 & - \\
\hline $\begin{array}{l}\text { Rata-rata kepemilikan sapi laktasi (average of lactating } \\
\text { cow ownership)* }\end{array}$ & $4,20 \pm 3,33$ & $4,20 \pm 3,33$ & - \\
\hline
\end{tabular}

* Responden sebanyak 50 orang peternak (the number of respondent was 50 head of farmers).

Tabel 3. Tingkat adopsi (adoption rate)

\begin{tabular}{|c|c|c|c|}
\hline $\begin{array}{c}\text { Jenis inovasi (types of } \\
\text { innovation) }\end{array}$ & $\begin{array}{c}\text { Jumlah peternak yang mendapat } \\
\text { informasi (orang) (amount of } \\
\text { farmers who received information } \\
\text { (people)) }\end{array}$ & $\begin{array}{l}\text { Jumlah peternak yang } \\
\text { adopsi (orang) (amount } \\
\text { of adopt farmers } \\
\text { (people)) }\end{array}$ & $\begin{array}{l}\text { Persentase peternak } \\
\text { yang adopsi }(0-100) \\
\text { (percentage of adopt } \\
\quad \text { farmer }(0-100))\end{array}$ \\
\hline & $(\mathrm{A})$ & (B) & $((\mathrm{B} / \mathrm{A}) \times 100)$ \\
\hline \multicolumn{4}{|l|}{ Pakan $(f e e d)$} \\
\hline $\begin{array}{l}\text { - Rumput unggul } \\
\text { (superior grass) }\end{array}$ & 50 & 48 & 96 \\
\hline - Leguminosa (legume) & 50 & 7 & 14 \\
\hline - Konsentrat (concentrate) & 50 & 50 & 100 \\
\hline - Silase (silage) & 9 & 1 & 11 \\
\hline \multicolumn{4}{|l|}{ Reproduksi (reproduction) } \\
\hline $\begin{array}{l}\text { - IB (artificial } \\
\text { insemination) }\end{array}$ & 50 & 48 & 96 \\
\hline \multicolumn{4}{|l|}{ Pemerahan (milking) } \\
\hline - Milk can & 50 & 22 & 44 \\
\hline Pencatatan (recording) & 50 & 21 & 42 \\
\hline \multicolumn{3}{|c|}{ Rerata (average) } & 57,57 \\
\hline
\end{tabular}

plastik bekas cat tembok untuk menampung susu. Bahkan ember tersebut terlihat sangat kotor bagian luarnya. Alat yang standar untuk menampung susu adalah milk can yang terbuat dari stainless steel. Peternak masih enggan menggunakan milk can karena harganya yang relatif mahal (Rp200.000,00-Rp500.000,00) sehingga mereka lebih memilih ember plastik yang lebih murah.

Peternak yang mengadopsi penggunaan pakan legume dan silase kurang dari $15 \%$. Hal tersebut dikarenakan masih sangat terbatasnya tanaman leguminosa seperti kaliandra, desmodium, rendeng kacang tanah, dan lainnya, yang terdapat di sekitar lokasi beternak. Legum dicirikan memiliki kandungan protein yang cukup tinggi yaitu sekitar $15 \%$ sampai 30\% (Bamualim et al., 2009).

\section{Industri inti}

Industri inti yang termasuk dalam klaster persusuan Jawa Tengah yaitu penampung susu yang menyetor susu ke IPS yang berbentuk koperasi. Koperasi susu memiliki peran yang besar dalam memasarkan susu dari peternak rakyat (Rusdiana dan Sejati, 2009). Susu yang diproduksi peternak untuk sampai ke koperasi ada yang melalui loper, kelompok tani ternak (KTT), ataupun langung ke koperasi. Terdapat enam buah koperasi susu, satu buah Gabungan Kelompok Tani Ternak (Gapoktan), dan satu buah KTT yang memakai Delivery Order (DO) KUD lain yang ada di Kabupaten Semarang. Gapoktan harus bekerja sama dengan koperasi untuk menyetor ke IPS karena IPS mengadakan perjanjian kerjasama dengan koperasi. Untuk itu, koperasi yang diajak bekerjasama akan mendapatkan insentif dari pembayaran susu yang dilakukan oleh IPS.

Penjualan susu dari peternak ke pengumpul ataupun koperasi, saat ini tidak berdasar bahwa penyetor harus merupakan anggota koperasi tersebut. Koperasi susu saat ini bersaing satu sama lain untuk mendapatkan pasokan susu dari peternak dan pengumpul skala kecil ataupun loper. Peternak biasanya mencari pembeli yang memberikan harga lebih tinggi, namun ada pula alasan lain yaitu 
pembeli (koperasi atau pengumpul lainnya) yang bersedia memberikan pinjaman pada peternak dengan pembayarannya diambil dari pembayaran susu.

Jumlah susu yang diproduksi oleh peternakan rakyat dan disetor ke koperasi susu untuk kemudian disetor ke IPS termasuk fluktuatif. Tabel 4 menunjukkan penyetor susu ke IPS yang terdapat di Kabupaten Semarang beserta rataan produksinya setiap hari.

Supplier susu segar bagi IPS tersebut memperoleh pasokan susu dari peternak di daerah sekitar Kabupaten Semarang dan Kota Salatiga. Rendahnya rata-rata produksi susu $(8,30 \pm 2,54$ 1/ekor/hari) dan banyaknya pesaing dalam mendapatkan pasokan susu membuat seringkali kesulitan dalam pemenuhan kuota kuantitas susu. Berbagai upaya perlu dilakukan untuk meningkatkan produksi susu,karena kebutuhan susu masyarakat masih tinggi dan kuota penerimaan susu oleh IPS belum terpenuhi. Kualitas susu yang disetor oleh koperasi ke IPS dapat dilihat dari data penerimaan oleh IPS (Tabel 5).

Kualitas susu yang diterima oleh IPS pada bulan September tahun 2011 sebagian besar memenuhi standar yang ditentukan oleh IPS, demikian pula rata-ratanya. Kandungan protein dari beberapa koperasi tidak memenuhi standar minimal yang ditentukan oleh IPS, akan tetapi masih ditoleransi untuk diterima, dengan konsekuensi harga yang lebih rendah sesuai dengan kualitasnya. Hal tersebut menunjukkan bahwa masih diperlukan peningkatan kualitas susu di tingkat koperasi agar memenuhi standar kualitas yang ditentukan.

Kualitas susu segar sangat mempengaruhi hasil olahan dari susu (Hanuš et al., 2004). Rendahnya rata-rata kualitas protein tersebut dapat disebabkan oleh rendahnya kualitas susu di tingkat peternak maupun penanganan susu oleh koperasi. Dari peternak sampai dikonsumsi, kualitas susu merupakan tanggung jawab produsen, penyalur, pengolah, distributor, dan retailer (Hassan et al., 2009). Cara untuk mengatasi hal ini yaitu dengan membina dan memantau peternak dalam manajemen pemeliharaan sapi perah dan pasca panen susu serta melakukan penanganan pengumpulan susu yang tepat oleh koperasi.

\section{Pembeli}

Pembeli susu terbesar dalam klaster industri susu di Jawa Tengah adalah IPS. Terdapat tiga IPS besar dan satu IPS menengah, seperti tersaji pada Tabel 6 beserta dengan kuota penerimaan susu tiap hari.

Setiap koperasi memiliki kerjasama masingmasing dengan IPS. Koperasi dapat menyetorkan susunya ke beberapa IPS. Masing-masing IPS memiliki jumlah kuota dan perjanjian kerjasama dengan koperasi susu sebagai supplier bahan baku susu segar. Selain Kabupaten Semarang, IPS ini

Tabel 4. Produksi susu di koperasi (milk production in cooperatives)

\begin{tabular}{lc}
\hline \hline \multicolumn{1}{c}{ Data supplier (data of the suppliers) } & Jumlah produksi (kg/hari) (milk production (kg/day)) \\
\hline KUD Getasan & 15.000 \\
KUD Andini Luhur & 30.000 \\
KUD Andini Luhur (Gapoktan Banyu Aji) & 2.300 \\
KUD Mekar Ungaran & 2.600 \\
KUD Sumber Karya Pabelan & 6.000 \\
KSU Wahyu Agung & 15.000 \\
KSU Sidodadi & 5.000 \\
KUD Banyumanik (KTT Ngudi Sari) & 1.400 \\
\multicolumn{1}{c}{ Jumlah (amount) } & 77.300 \\
\hline
\end{tabular}

Tabel 5. Kualitas susu koperasi pada bulan September 2011 (milk quality of cooperatives in September 2011)

\begin{tabular}{|c|c|c|c|c|c|c|c|}
\hline \multirow{2}{*}{$\begin{array}{c}\text { Koperasi } \\
\text { (cooperatives } \\
\text { supplier) }\end{array}$} & $\mathrm{pH}$ & TS (\%) & $\begin{array}{c}\text { Lemak (\%) } \\
(\text { fat }(\%))\end{array}$ & \multirow[t]{2}{*}{ SNF (\%) } & Protein $(\%)$ & \multirow[t]{2}{*}{$\begin{array}{c}\mathrm{BJ} \\
\left(27,5^{\circ} \mathrm{C}\right)\end{array}$} & \multirow{2}{*}{$\begin{array}{l}\text { Laktosa }(\%) \\
(\text { lactose }(\%)) \\
4,0-4,6 \%\end{array}$} \\
\hline & $6,60-6,84$ & $\operatorname{Min} 11 \%$ & Min 3\% & & $\operatorname{Min} 2,7 \%$ & & \\
\hline Andini Luhur & 6,79 & 11,12 & 3,41 & 7,72 & 2,63 & 1,0262 & 4,57 \\
\hline Andini Luhur 2 & 6,78 & 11,14 & 3,41 & 7,73 & 2,64 & 1,0262 & 4,58 \\
\hline Banyumanik & 6,74 & 11,14 & 3,63 & 7,51 & 2,67 & 1,0261 & 4,24 \\
\hline Getasan & 6,77 & 11,37 & 3,59 & 7,79 & 2,77 & 1,0268 & 4,42 \\
\hline Pabelan & 6,80 & 11,26 & 3,65 & 7,62 & 2,65 & 1,0262 & 4,47 \\
\hline Ungaran & 6,78 & 11,34 & 3,61 & 7,73 & 2,71 & 1,0267 & 4,42 \\
\hline Rerata (average) & 6,78 & 11,23 & 3,55 & 7,68 & 2,68 & 1,0264 & 4,45 \\
\hline
\end{tabular}

TS: total solid (jumlah padatan), SNF: solid non fat (padatan tanpa lemak), BJ: berat jenis (density). 
Tabel 6. Daftar IPS dan kuota penerimaan susu (list of dairy processing industries and acceptance of milk quotas)

\begin{tabular}{lc}
\hline \hline \multicolumn{1}{c}{ Pengolah susu (milk industries) } & Kuota (kg/hari) (quota of milk acceptance $(\mathrm{kg} /$ day $)$ ) \\
\hline PT. Indolakto & 45.000 \\
PT. FFI & 120.000 \\
PT. Sari Husada & 27.000 \\
CV. Cita Nasional $\quad 20.000$ \\
\multicolumn{1}{c}{ Jumlah (total amount) } & 212.000 \\
\hline
\end{tabular}

mengambil bahan baku dari koperasi susu yang lain di Jawa Tengah. Gambar 2 menggambarkan aliran penjualan susu koperasi di Kabupaten Semarang ke IPS.

Koperasi menjalin kerja sama dengan beberapa IPS dan masing-masing IPS memiliki perjanjian kuota dan kualitas penyetoran susu yang berbeda. Hal ini memberikan keuntungan kepada koperasi apabila penyetoran kepada salah satu IPS ditolak, maka ada alternatif pemasaran ke IPS yang lain. Kelemahan dari sistem ini yaitu kualitas susu di tingkat koperasi menjadi sulit dinaikkan.

Sejauh ini, koperasi penyetor susu ke IPS masih belum memenuhi kuota yang diberikan oleh IPS, sehingga masih terdapat peluang yang cukup besar untuk meningkatkan produksi susu. IPS memiliki standar masing-masing dalam hal kualitas susu. Hal tersebut menentukan besarnya harga susu dan diterima atau tidaknya susu dari penyetor. Masing-masing IPS memiliki staf KUD service, yaitu staf yang berhubungan langsung dengan KUD penyetor bahan baku susu dan memberikan pem- binaan demi melakukan perbaikan kualitas dan peningkatan kuantitas.

\section{Industri terkait}

Industri pengolahan susu skala kecil atau usaha olahan susu merupakan industri terkait dalam klaster industri persusuan di Jawa Tengah. Industri ini menggunakan bahan baku susu, sama halnya dengan koperasi-koperasi membeli susu dari kelompok tani ternak. Daftar industri olahan susu di Kabupaten Semarang dan sekitarnya yang memperoleh pasokan susu dari Kabupaten Semarang, tersaji pada Tabel 7.

\section{Industri pendukung}

Bantuan modal dari perbankan dapat membantu perkembangan usaha persusuan di Kabupaten Semarang jika modal tersebut digunakan dengan baik. Peternak, KTT, Gapoktan, dan juga dapat mengakses kredit perbankan untuk mengembangkan usahanya. Resiko yang ada yaitu jika usaha sedang kurang baik, maka bisa jadi kesulitan untuk

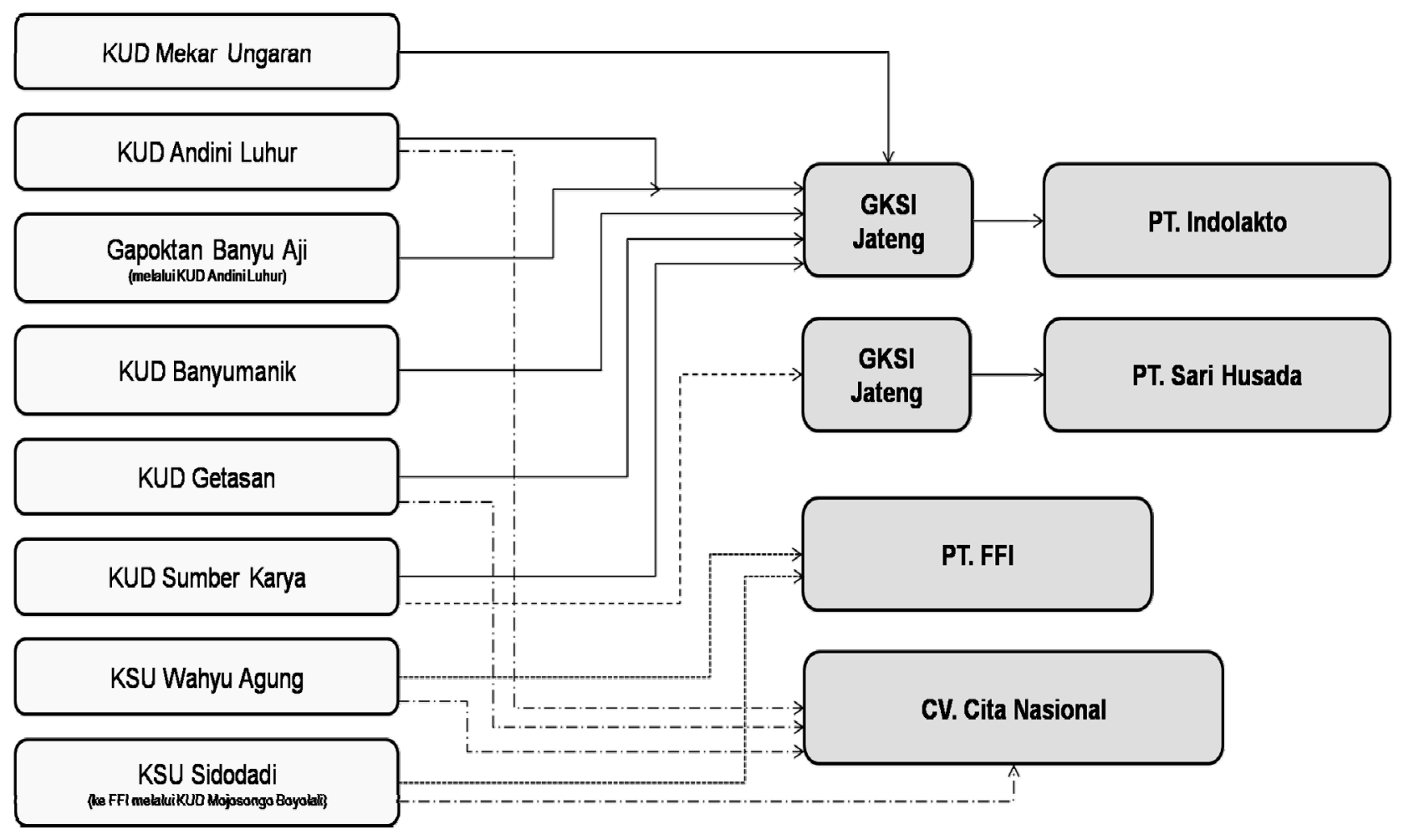

Gambar 2. Bagan aliran penjualan susu ke IPS tahun 2011 (chart of milk sales flow to dairy processing industries in 2011). 
Tabel 7. Daftar pengusaha dan perusahaan pengolahan susu (list of small dairy processing industries)

\begin{tabular}{|c|c|c|c|}
\hline $\begin{array}{l}\text { Pengusaha/perusahaan } \\
\text { (producer/firm) }\end{array}$ & Produk (product) & $\begin{array}{c}\text { Alamat } \\
\text { (address) }\end{array}$ & $\begin{array}{c}\text { Omset/kebutuhan susu (requirement } \\
\text { of milk) }\end{array}$ \\
\hline $\begin{array}{l}\text { Gedono Standard } \\
\text { Operational Procedure }\end{array}$ & Kefir & Kec. Getasan & Sesuai pesanan (by order) \\
\hline Suryantoro & Kefir & Kec. Getasan & Sesuai pesanan (by order) \\
\hline Umi & Sabun susu (milk soap) & Kec. Suruh & $6.000 \mathrm{buah} / \mathrm{b} \ln (6.000$ pieces $/$ month $)$ \\
\hline Saud & Sabun susu (milk soap) & Kec. Ungaran & $2.000 \mathrm{buah} / \mathrm{bln}$ (2.000 pieces/month $)$ \\
\hline Suryantoro & Sabun susu (milk soap) & Kec. Getasan & $4.000 \mathrm{buah} / \mathrm{bln}$ ( 4.000 pieces $/$ month $)$ \\
\hline Ngudisari & Sabun susu (milk soap) & Kec. Getasan & 20-60 1/hari (20-60 l/day) \\
\hline Layina & Sabun susu (milk soap) & Kec. Tengaran & Sesuai pesanan (by order) \\
\hline Lerep & Kerupuk susu (milk crackers) & Kec. Ungaran & - \\
\hline Ngudisari & Kerupuk susu (milk crackers) & Kec. Getasan & - \\
\hline $\begin{array}{l}\text { CV. Cempaka Bukit } \\
\text { Baros Salatiga }\end{array}$ & Keju (cheese) & Kota Salatiga & $1.500-2000 \mathrm{l} / \mathrm{hr}(1.500-2.000 \mathrm{l} /$ day $)$ \\
\hline
\end{tabular}

mengangsur kredit yang diberikan. Akses permodalan untuk peternakan sapi perah di Kabupaten Semarang dapat diakses dengan mudah oleh KTT maupun koperasi, sehingga merupakan kekuatan pendukung dalam pengembangan klaster industri persusuan. Bank Indonesia (2011) menyatakan bahwa pada tahun 2011, jumlah realisasi kredit untuk usaha sapi perah sebesar Rp24.892.000.000,00. Jumlah tersebut direalisasikan oleh Bank Jateng Ungaran sebesar Rp7.540.000.000,00 dan Bank BRI Ungaran sebesar Rp17.352.000.000,00.

\section{Institusi pendukung}

Perkembangan industri persusuan di suatu daerah tidak dapat lepas dari peran pemerintah, demikian pula di Kabupaten Semarang. Beberapa dinas terkait yang mengurusi bidang persusuan terdapat dalam pemerintahan daerah Kabupaten Semarang. Dinas Peternakan dan Perikanan telah menjalankan perannya dalam peningkatan kemampuan peternak serta penerapan teknologi tepatguna, namun hasil yang diharapkan masih belum sesuai. Peran lainnya yaitu dalam pencegahan dan penanggulangan penyakit hewan, yang hasilnya sudah sesuai harapan.

Dinas Perindustrian dan Perdagangan sudah menjalankan peran fasilitasi hubungan kerjasama, fasilitasi pengadaan dan penyaluran barang dan jasa, serta penyelenggaraan bimbingan dan latihan industri dan perdagangan. Hasil yang didapatkan masih belum sesuai dengan harapan. Dinas Koperasi dan UMKM telah menjalankan peran dalam pembinaan dan fasilitasi pada koperasi, namun hasil yang diperoleh belum sesuai dengan harapan. Institusi pendukung lainnya dalam pengembangan klaster industri persusuan di Kabupaten Semarang yaitu perguruan tinggi dan Gabungan Koperasi Susu Indonesia (GKSI) Jawa Tengah.

\section{Kesimpulan}

Dinamika dari masing-masing elemen klaster yang mengarah pada klaster dinamis yaitu rata-rata tingkat adopsi lebih dari 50\%, sebagian besar parameter kualitas susu memenuhi standar, kuota penerimaan IPS cukup tinggi, banyaknya industri terkait, adanya akses permodalan dari bank, dan adanya institusi pendukung yang menjalankan perannya masing-masing dalam pengembangan klaster industri persusuan. Dinamika yang belum mengarah pada klaster dinamis yaitu produksi susu rendah dan rata-rata kualitas protein susu di bawah standar.

\section{Daftar Pustaka}

Badan Pengkajian dan Penerapan Teknologi (BPPT). 2011. Panduan Pengembangan Klaster Industri. Badan Pengkajian dan Penerapan Teknologi (BPPT). Jakarta.

Bamualim, A. M., Kusmartono, dan Kuswandi. 2009. Aspek Nutrisi Sapi Perah. Profil Usaha Peternakan Sapi Perah di Indonesia. Pusat Penelitian dan Pengembangan Peternakan, Badan Penelitian dan Pengembangan Pertanian. LIPI Press. Jakarta.

Bank Indonesia. 2011. Pengembangan Sapi Perah dan Sapi Potong melalui Fasilitasi Percepatan Pemberdayaan Ekonomi Daerah (FPPED) di Kabupaten Semarang dan Kabupaten Grobogan. Bank Indonesia Semarang. Semarang.

Bebe, B. O., H. M. J. Udo, G. J. Rowlands and W. Thorpe. 2003. Smallholder dairy systems in the Kenya highlands: cattle population dynamics under increasing intensification. Lives. Prod. Sci. 82: 211-221.

Cooper, D. and P. S. Schindler. 2006. Business Research Methods $9^{\text {th }}$ Edition. McGraw Hill Education. New York. 
Gereffi, G., J. Humphrey, R. Kaplinsky and T. Sturgeon. 2001. Introduction: globalization, value chains, and development. IDS Bulletin 32.3: $1-12$.

Hanuš, O., J. Frelich, M. Vyletělová, P. Roubal, Z. Vorlícěk and R. Jedelská. 2004. Technologically difficult, pathogenic and food risky bacterial contamination of raw milk and other materials from dairy cow herds. Czech J. Anim. Sci. 49: 489-499.

Hassan, N. B. A., M. O. M. Abdalla and A. A. A. M. Nour. 2009. Microbiological Quality of Heat-Treated Milk During Storage. Pakistan J. Nutr. 8: 1845-1848.

Kaplinsky, R. 2000. Spreading the gains from globalizations: what can be learned from value chain analysis. IDS working paper. United Kingdom.

Porter, M. E. 2002. Competition and Antitrust: A Productivity-Based Approach. Conference Board's "2002 Antitrust Conference: Antitrust Issues in Today's Economy" (New York, March 7-8, 2002).
Prasetyo, T. 2008. Arah pengembangan industri sapi perah di Jawa Tengah. Semiloka Nasional Prospek Industri Sapi Perah Menuju Perdagangan Bebas- 2020. Available at http://peternakan.litbang.deptan.go.id/fullteks /lokakarya/loksp08-77.pdf. Accession date: 1 Februari, 2012.

Rusdiana, S. dan W. K. Sejati. 2009. Upaya pengembangan agribisnis sapi perah dan peningkatan produksi susu melalui pemberdayaan koperasi susu. Forum Penelitian Agroekonomi 27. Available at http://pse.litbang.deptan.go.id/ind/pdffiles/FA E27-1d.pdf. Accession date: 1 Februari, 2012.

Vissers, M. 2007. Modeling to control spores in raw milk. Thesis Wageningen University. Netherland.

Xiaohui, W., H. Zhijun and Y. Shichun. 2006. Study of relation and condition of regional industri cluster on the Niche theory and model. Can. Soc. Sci. 2: 27-31. 